\title{
The Big Influence of a Small State: The Perry Process and the Influence of the Kim Dae-jung Government
}

\author{
Ahn, Mun Suk \\ (Korean unification affairs in Political and \\ Foreign Affairs Team, N ews Center of KBS)
}

\section{$\langle$ CONTENTS〉}

I . Introduction

II. Realist and Liberal Approach

1. Realist Approach

2. Liberal Approach

III. Divergence between the ROK and the U.S.

1. Broken Uneasy Truce in the U.S.

2. Optimism in South Korea

IV. Compromise between the ROK and the U.S and the Perry Process

$\mathrm{V}$. Influence of the ROK

1. Shared Values: Political Liberalism, Democracy and Engagement of North Korea

2. Consultation Norms: Government-level Consultations,
Policy Consistency, Leadership Beliefs and International Organization

3. Transnational, Transgovernmental and Cross-level Coalitions

4. Domestic Pressures: Public Opinion and the Press

VI. Factors and Circumstances for the ROK Influence

1. Common Views

2. Leadership Beliefs, Policy Consistency and International Organizations

3. Transboundary Coalitions

4. Domestic Pressures

VII. Conclusion

- Keyword: influence, liberal approach, consultation norms, consistency of policy, leadership beliefs

\section{【ABSTRACT】}

This article examines South Korean influence on the U.S. in the post-Cold era. It argues that South Korea can exert influence effectively on U.S. policy by virtue of the liberal approach. In particular, it emphasizes the importance of consultation norms, consistency of policy, leadership beliefs and international organizations in the process of influence. 
Traditional realists and liberals admit room for small states' impact vis-a-vis large states. However, most research in small-large state relations has been confined to the Cold War era and to Western states. This article expands the range of small-large state studies to the post-Cold War era and to East Asia. The world order in the post-Cold War era is totally different from that of the Cold War era. The ideological blocs collapsed and small states' foreign policy needs to be adjusted in this new world order. By enquiring into South Korean foreign policy in the-post Cold War era, this article shows that South Korea came to have a more balanced security relationship with the U.S. by adopting liberal mechanisms in the postCold War era. This article analyzes the 1999 Perry process. It involves policy towards North Korea as well as the nuclear issue. This paper tries to put forward a convincing explanation for South Korea to have an impact on the U.S. by exploring the significant issue for U.S. foreign policy. This paper scrutinizes newly declassified documents and is based upon semi-structured elite interviews.

This study measures influence by assessing ROK-U.S. interaction and U.S. policy changes. It concludes that small states can wield influence on large states and that the liberal approach is effective for small states' influence on large states in the post Cold War era. It also confirms that South Korea is no longer a client who complies with the patron, namely the U.S.

\section{I . Introduction}

The North Korean nuclear issue is still a big concern in East Asian security. A serious nuclear issue after the 1993-1994 crisis occurred in August 1998 when U.S. intelligence revealed the construction of an underground site at Kumchangni in North Korea(or DPRK, Democratic People's Republic of Korea). ${ }^{1)}$ Time and the New York Times reported on the North Korean suspected nuclear site at Kumchangni, 25 miles northeast of Yongbyon, the North's main nuclear complex. ${ }^{2}$ The New York Times reported in detail

1) William Perry, Testimony before the Committee of International Relations, House of Representatives, 106 th Congress, $1^{\text {st }}$ Session, October 13, 1999.

2) J.F.O. McAllister, "Is North Korea the latest to proliferate?" Time, August 10, 1998, p.24.; David E. Sanger, "North Korea Site an a-Bomb Plant, U.S. Agencies Say" New York Times, August 17, 1998, p.1. 
that thousands of North Korean workers were swarming around the new site, burrowing into the mountainside, and that US intelligence analysts believed the North intended to build a new nuclear reactor and reprocessing centre under the mountain. The issue became a serious concern of the U.S. and Northeast Asian countries. The U.S. government demanded the site should be inspected soon, warning that it would not be able to uphold the 1994 Agreed Framework unless Pyongyang agreed to the inspections of the suspect site. North Korea rebutted the U.S. demand and asserted the site was a military facility irrelevant to the nuclear programme and the inspection of such a facility must be an infringement of sovereignty.

In this tension, the Kim Dae-jung government intervened in the dispute between the DPRK and the U.S. The South Korean government attempted to make its voice heard in the review of U.S. North Korea policy and to persuade the Washington government not to move to containment and even transfer to a more engagement-oriented policy. The U.S. and the DPRK reached agreement that the U.S. would inspect the Kumchangni site in return for provision of 600,000 tons of food aid, and another agreement that the U.S would ease its economic sanctions on North Korea in exchange for the North's test moratorium for longrange missiles. The attempt of South Korea(or ROK, Republic of Korea) was especially focused on the Perry report issued in October 1999. The report recommended that the U.S. should lift economic sanctions and normalize the DPRK-U.S. relationship on condition that the North stopped developing nuclear weapons and missiles. This process(called the Perry process) was very close to the 'package deal' which was initiated by the ROK government.

This article shows the specific influence of South Korea over U.S. decision-making on North Korea policy and investigates the concrete process of the influence. It focuses mainly on South Korean resources, opportunities and strategies to exercise that influence and concludes that the Kim Dae-jung government affected the foreign policy of the Clinton Administration since it adopted liberal mechanisms such as consultation norms and transnational coalitions.

\section{Realist and Liberal Approach}

\section{Realist Approach}

Classical realism anticipates the small state's influence in balances of power in 
international politics. A small power can be influential in an alliance regardless of the actual distribution of material power if it possesses an asset which is of great value for the alliance leader. ${ }^{3)}$ Handel argues that small states - despite the situation of limited autonomy - can influence the foreign policies of large states. He maintains that when competition between the superpowers is intense, it allows latitude for small states to make decisions more freely and exert impact on the policies of the superpowers. ${ }^{4)}$ According to Handel's analysis, weak states can alter the orientation of large states' foreign policy by realistic bargaining rather than by cooperation. He adduces "appeal to public opinion," "manipulation," "mutual dependence" and "neutralist position" as the significant policy tools for exerting influence.

As can be seen in the case of the Republic of China(Taiwan) after the Second World War, appeal to public opinion can be a way to affect the superpower. ${ }^{5)}$ Another method for small states to exercise impact is to manipulate a great power. Poland refused the request of the United Kingdom and the U.S. to allow Soviet troops to fight on Polish soil. The refusal led to the collapse of the British-French-Russian talks and the formation of the Soviet-Nazi Pact. $\left.{ }^{6}\right)$ Handel notes that small states may exercise influence over large states' foreign policy through the relationship of mutual dependence. The ROK government sent its troops to the Vietnam War to comply with the American request and in return, the United States strengthened its commitment to Korea's security and gave economic benefits. ${ }^{7)}$ A neutralist position can be an effective way to enhance the value of small states especially in the bipolar system. ${ }^{8)}$ To summarize, small states - although they are weak in economic and military strength in comparison with large states - are not totally deprived of power to affect great powers.

\section{Liberal Approach}

Liberals observe that small states are also likely to rely not on the use of force as a technique of state-craft but on international legal norms due to their limited military capabilities. ${ }^{9)}$ More specifically, Keohane emphasizes the value of cooperative ties

3) Hans Morgenthau, Politics Among Nations: The Struggle for Power and Peace, Sixth Edition, Revised by Kenneth W. Thompson (New York: McGraw-Hill, Inc., 1985), p.205.

4) Michael Handel, Weak States in the International System (London: Frank Cass, 1981), p.194.

5) Ibid., pp.126-127.

6) Ibid., p.130.

7) Ibid., pp.142-143.

8) Ibid., p.191. 
between small states' officials and powerful elements of great powers' society. He notes that such ties enable small states to take advantage of the fact that "U.S. policy is largely the outcome of clash and compromising among separate groups and bureaucratic units. " ${ }^{10)}$ Risse-Kappen's prominent argument is that small states might exert a big influence on the foreign policy of large states through cooperation between democratic nations. His arguments include three elements related to liberalism as a paradigm. First, the fundamental actor in international relations is the individual rather than the state. Second, the interests and preferences of states have to be investigated "as a result of domestic structures and coalition-building processes" reflecting social demands and the international system. Third, "international institutions ${ }^{11)}$ form the social structure of international politics presenting constraints and opportunities to state actors." ${ }^{12}$ )

Following Kant's argument, he points to republicanism, institutionalism, and transnationalism as the significant strands of liberal approaches to international relations. ${ }^{13)}$ According to Risse-Kappen, a republican constitution is a political system which guarantees the freedom of the individual, the rule of law, and the equality of the citizens before the law. Such republics keep the peace since they are equipped with "the democratic norms governing domestic decision-making processes." Because of the democratic norms, democracies establish "pluralistic security communities of shared values." ${ }^{14)}$ Democracies are likely to build up international institutions such as alliances since "they perceive each other as peaceful and express a sense of community". The norms which encompass such institutions tend to comply with the democratic values. The very norms allow latitude for small states to affect foreign policies of great powers in democratic

9) George L. Reid, The Impact of Very Small Size on the International Behavior of Microstates (London: Sage Publications, 1974), p.14.

10) Robert Keohane, "The Big Influence of Small Allies," Foreign Policy 2, 1971, p.164.

11) Risse-Kappen's conception of institution, following Robert O. Keohane, is "persistent and connected sets of rules that prescribe behavioral roles, constrain activity, and shape expectation". See Robert O. Keohane, International Institution and State Power (Boulder, Colorado: Westview, 1989), p.3.

12) Thomas Risse-Kappen, Cooperation among Democracies: The European Influence on U.S. Foreign Polics, (Princeton: Princeton University Press, 1995), p.25.

13) Ibid., pp.27-28.

14) Ibid. "Pluralistic security community" is the terminology which was generated by Deutsch and his colleagues. It means "a community in which there is real assurance that the members of that community will not fight each other physically, but will settle their disputes in some other way." They cite Canada-United States and Norway-Sweden as salient examples. In contrast to their view, Jervis asserts that there are no cases of a pluralistic security community and instead, concert systems which are the closest to the pluralistic security community has occurred three times in modern history - from 1815 to 1854, 1919 to 1920 and 1945 to 1946. See Karl W. Deutsch, et al., 
international institutions. ${ }^{15)}$ As to transnationalism which is defined as "transboundary interactions that include at least one nonstate actor", Risse-Kappen holds that domestic political processes can affect relations among democratic allies through transnational coalition-building. Transnational coalitions take part in the domestic political processes and small allies are expected to exert an impact on an alliance leader through the coalitions. ${ }^{16)}$

In sum, the process of cooperation and influence between small and large states proceeds through "collective identity", "consultation norms", "the interplay of domestic politics", and "transnational coalitions". The first one acts as a condition under which cooperation between small and large states can be reinforced and the latter three function as policy tools which promote the cooperation. "Collective identity", the content of which refers to shared values such as human rights, the rule of law, and democratic governance, ensues if democratic nations transact in "an institutionalized setting such as an alliance". The cooperative relations between the ally and its leader are institutionalized in "the norms of interallied consultation." "Consultation norms" provide room for allies to exercise influence on the policies of alliance leader. Domestic pressures in democracies play a significant role in increasing their bargaining leverage vis-à-vis each other. While the conception of interstate relations is blurred in institutionalized alliances between democracies, transnational and transgovernmental coalitions are regarded as an efficient and important way to influence. ${ }^{17}$

The Kim Dae-jung government employed the liberal approach rather than the realist one. It tried to have consultations with the U.S. and to establish consultation norms. Policy consistency and leadership beliefs contributed to close consultations. The Kim government also adopted transnational coalitions and domestic pressures. These liberal tools were effective in influencing the American administration.

Political community and the North Atlantic area: International Organization (Westport, Connecticut: Greenwood Press, 1969), pp.5-7 and Robert Jervis, "From Balance to Concert: A Study of International Security Cooperation," in Cooperation under Anarchy, edited by Kenneth Oye, Princeton, N. J: Princeton Universithy Press, 1986, p.58.

15) Risse-Kappen, op. cit., p.33.

16) Ibid., pp.38-39.

17) Ibid., pp.204-208. 


\section{Divergence between the ROK and the U.S.}

\section{Broken Uneasy Truce in the U.S.}

No sooner had the Kumchangni site been revealed than Charles Kartman, U.S. Special Envoy for Korean Affairs, delivered a strong warning to North Korean Vice Foreign Minister Kim Gye-kwan that an underground tunnel reaching Yongbyon should not be built. ${ }^{18)}$ He stated, in November 1998, that there was "compelling evidence" which would show it was a nuclear facility. ${ }^{19)}$ Defence Secretary William Cohen stepped up the warning: "It would seem to me not to be a prudent course to wait until the facility is completed and then ask for inspection." ${ }^{20)}$ Deputy Assistant Secretary of Defence Kurt Campbell admitted that vigilance in the Pentagon at the time was very high. ${ }^{21}$

A more hard-line atmosphere was found in Congress. The United States Institute of Peace - which was created by Congress and is subject to its mandate - claimed, through a special report published in October 1998, that the suspect Kumchangni site and the missile test were a direct challenge to the Clinton administration which had applied diplomatic measures to prevent the proliferation of weapons of mass destruction and warned that an unwillingness to challenge North Korea now with a deterrence policy would risk being confronted later by a qualitatively different North Korean military threat. ${ }^{22)}$ The Republicans publicly insisted on more pressure on the North. After the North's long-range missile test, Republican Senator McCain argued that the U.S. should cut off all funding to KEDO(Korean Peninsular Energy Development Organization). ${ }^{23}$ Not only the Republicans but the Democrats became less supportive of the policy of engagement of North Korea. Before the missile test, Congress had provided regular appropriation for KEDO and food assistance. It seemed that the connections between the DPRK and the U.S. were increasing. ${ }^{24)}$ According to Mark Kirk, Counsel to the International Relations Committee of the House 1998-1999, he talked to North

18) Washington Post, August 22, 1998, p.A10.

19) Munhwa Ilbo, November 20, 1998, p.3.

20) William Cohen, Defence Secretary, News Conference, November 23, 1998.

21) Interview with Kurt Campbell, Deputy Assistant Secretary of Defence 1995-2000, CSIS (Center for Strategic and International Studies), October 6, 2004.

22) United States Institute of Peace, Mistrust and the Korean Peninsula: Dangers of Miscalculation, Special Report 38, October 1998.

23) Congressional Record, Vol.144.(Washington, D.C.: U.S. Government Printing Office, 1998), p.D928.

24) Interview with Mark Kirk, Counsel to the International Relations Committee in the House 19981999, Longworth House Office Building, Washington, March 23, 2004. 
Korean Minister to the UN Han Song-ryol and North Korean Deputy Ambassador to the UN Lee Guen about once a week and there was a better and better relationship. Yet, after the missile test, "the Republicans went from being very suspicious but positive to negative and the Democrats went from being positive to embarrassed." ${ }^{25)}$ Under these circumstances, Congress passed a resolution, on October 8, 1998, which expressed the sense of the Congress that the commitment made by the United States to arrange the financing and construction of 2 nuclear reactors for North Korea, and to provide fuel oil and other assistance to North Korea, should be suspended until the President certified that North Korea had agreed to cease further development of its ballistic missile programme and all aspects of its nuclear weapons development programme. ${ }^{26)}$ The Senate and the House of Representatives passed a bill to tie U.S. KEDO funding to presidential certifications that Pyongyang would not actively pursue a nuclear weapons capability or export ballistic missile technology to countries that support terrorism. ${ }^{27)}$ This hard-line trend bred the prospect of a crisis in May 1999. ${ }^{28)}$

As a whole, the "uneasy truce" in the U.S. in regard to North Korea broke down in 1998. After the 1994 Agreed Framework, there was an "uneasy truce" between proponents of engagement and opponents of engagement most of whom were in Congress. The uneasy truce broke down in the wake of the Kumchangni issue and the missile test in $1998{ }^{29)}$

\section{Optimism in South Korea}

In contrast to the Americans, the South Korean government emphasized that there was no obvious evidence which could verify it was linked to the nuclear development. The South Korean government convened a standing committee meeting of the National Security Council(NSC) to discuss the Kumchangni issue on August 27, 1998 and declared that there was a suspicion that the site was nuclear-related, but no evidence was found

25) Interview with Mark Kirk, Counsel to the International Relations Committee in the House 19981999.

26) Expressing the sense of the Congress that the commitment made by the United States, in conjunction with South Korea and Japan, to arrange financing and construction of 2 nuclear reactors for North Korea, and to provide fuel oil and other assistance to North Korea, should be suspended until North Korea no longer poses a nuclear threat to the peace and security of Northeast Asia or the United States., H.CON.RES.341., 105 ${ }^{\text {th }}$ Congress, $2^{\text {nd }}$ Session, October 8, 1998.

27) Congressional Record, Vol.144.(Washington, D.C.: U.S. Government Printing Office, 1998), p.S9826-S9828, S9837-S9838, S9841, S9845-S9847, S9861-S9863.; Korea Times, September 20, 1998.

28) Joongang Ilbo, Editorial, January 9, 1999., p.6.

29) Interview with Joel Wit, Coordinator for the 1994 U.S.-North Korea Agreed Framework 1998-1999, Center for Strategic and International Studies, March 23, 2004. 
and there was no reason for serious concern yet. ${ }^{30)}$ President Kim said, at a press conference in November 1998, that there was no evidence but a suspicion that the Kumchangni underground construction was linked to the nuclear programme. ${ }^{31)}$

Furthermore, the South Korean government also believed that it was not a breach of the 1994 Agreed Framework, even though North Korea had built a nuclear facility in a place other than Yongbyon because the agreement did not address suspicions on the North's nuclear development in other regions. Song Min-soon, Director for North American Affairs at the Foreign Affairs and Trade Ministry, said to news reporters, "If there are nuclear facilities in other regions, the United States has no right to demand inspection of them." ${ }^{32)}$ This interpretation of the agreement differed from that of the Americans. Chief negotiator of the agreement, Robert Gallucci made clear, at an interview with Segye Ilbo, that it meant a breakdown of the agreement if the Kumchangni site was a nuclear facility. ${ }^{33)}$ It was the Americans' conception that it was natural that the 1994 Agreed Framework would not allow any other regions for a nuclear development since the agreement was mainly aimed at a freeze of the North's nuclear ambition in return for an energy compensation and a promise to normalize the two nations' diplomatic ties.

As to the missile issue, President Kim stressed that North Korea had never promised to abstain from developing missiles. ${ }^{34)}$ However, Robert Gallucci argued that the missile issue was also dealt with in the negotiations in 1994 and that the North acquiesced in a missile moratorium in the political objectives of the 1994 Agreed Framework because the two sides agreed to move towards full normalization of political and economic relations. ${ }^{35}$

\section{Compromise between the ROK and the U.S and the Perry Process}

William Perry issued his report in September 1999 after a ten-month review of U.S. North Korea policy. The report recommended that the U.S. should pursue a comprehensive and integrated approach in dealing with the DPRK. If the DPRK was

30) Chosun Ilbo, August 28, 1998., p.1.

31) Hankook Ilbo, November 21, 1998., p.1.

32) Korea Herald, October 26, 1999., p.3.

33) Segye Ilbo, January 1, 1999., p.6.

34) Los Angeles Times, February 13, 1999., p.4.

35) Segye Ilbo, January 1, 1999., p.6. 
willing to give assurances that the North did not have a nuclear weapon programme and to cease testing, production and development of missiles, the U.S government would be willing to move to reduce pressures on the DPRK such as presidentially-mandated trade embargo measures. If the DPRK moved to eliminate its nuclear and long-range missile threats, the U.S. would normalize relations with the DPRK, relax sanctions that have long constrained trade with the DPRK and take other positive steps that would provide opportunities for the DPRK. Alternatively, if North Korea would not demonstrate by its actions that it was willing to remove the threat, the U.S. would have to take action to contain the threat. ${ }^{36)}$ These recommendations were close to the "comprehensive approach" initiated by the South Korean government. Under the approach, Seoul urged Washington to lift economic sanctions and eventually recognize North Korea diplomatically in return for North Korea's abandonment of nuclear and missile programmes including U.S. access to the suspicious facilities. ${ }^{37)}$

As to the "red line," its definition in the Perry report is still categorized as a secret. Though the clear concept of the red line in the report has not been publicized, yet, at the time, it was asserted that if North Korea would not respond to the path of engagement and attempted to transfer enriched uranium or plutonium out of North Korea, she would be attacked almost immediately. ${ }^{38)}$ The ROK objected to even designating a red line, but later agreed to drawing the line. South Korea, however, led the U.S. to agree to consult with the ROK government over the concrete policy orientations towards North Korea after violation of the red line. ${ }^{39)}$ The specific contents of the reaction to crossing the red line are not declassified yet. However, ROK and U.S. diplomats admit that American willingness to put pressure on North Korea was moderated by the South Korean request. Kim Young-mok, Deputy Director of North American Affairs Bureau of the Ministry of Foreign Affairs and Trade 1998-2000, said, "the U.S. government attempted to include various and specific measures of sanction in the Perry report to prepare for the failure of the engagement policy, but the Seoul government did not agree to the American plan. In the end, the two governments

36) Review of United States Policy Toward North Korea: Findings and Recommendations, Unclassified Report by Dr. William J. Perry, U.S. North Korea Policy Coordinator and Special Advisor to the President and the Secretary of State, Washington, D.C., October 12, 1999, p.8-10. The unclassified Perry report did not reveal the concrete contents of the second path to assure security and contain the threat, which were included in another confidential report by Perry.

37) Joongang Ilbo, December 8, 1998., p.1.

38) Interview with Mark Kirk, Counsel to the International Relations Committee of the House 19981999.

39) Hangyoreh Shinmun, March 10, 1999., p.3. 
compromised." ${ }^{40)}$ Stephen Bosworth, U.S. Ambassador to South Korea 1997-2001, implied that the ROK and the U.S. had compromised to reduce economic aid and trade if the DPRK would not accept U.S. proposals by saying, "I think there was general understanding that if North Korea did not respond positively to US concerns, then in effect they will begin to see less movement by South Korea on the question of economic engagement". ${ }^{41)}$

William Perry himself had been inclined to put pressure upon North Korea. He had played a key role in planning to attack the Yongbyon nuclear site as Secretary of Defense in 1994. Even at the time of appointment as Policy Coordinator on North Korea, he, along with President Clinton and his aides, had been negative over the South Korean government's Sunshine Policy. He revealed his thinking in Preventive Defense published in March 1999 by writing that he and his colleague(Ashton Carter) with President Clinton and his advisers, and with many members of Congress, agreed that a continuing weapons of mass destruction programme in North Korea would rob them of the time needed for Kim Dae-jung's engagement policy to work and that unless a solution to the problem were found, the situation could easily end up in a confrontation like that of the summer of $1994{ }^{42}$ ) Judging from this line of his thinking, analysts predicted that his report would be in favour of the hard-line policy. ${ }^{43)}$

However, his stance had gradually changed in the process of coordination with South Korea, Japan and China. Perry said to Congress in October 1999, "Others advised us that if the United States simply put enough pressure on North Korea, we could cause the regime to collapse. We did not believe that this strategy was likely to succeed." ${ }^{44)}$ This statement made clear that his attitude towards North Korea had totally changed from that expressed in Preventive Defense. The statement also had in common an assumption

40) Interview with Kim Young-mok, Deputy Director of North Korean Affairs of the Ministry of Foreign Affairs and Trade 1998-2000, Intercontinental Hotel in New York, March 26, 2004.

41) Interview with Stephen Bosworth, U.S. Ambassador to South Korea 1997-2001, Fletcher School, Tufts University, Massachussets, March 30, 2004.

42) Ashton Carter and William Perry, Preventive Defense (Washington, D.C.: Brookings Institution Press, 1999), p.221.

43) For instance, Stephen Noerper, Associate Professor of the Asia-Pacific Center for Security Studies, said that Perry was the only person in Washington who could review North Korea policy because he had an amicable relationship with Congress and he would choose a more hawkish policy towards North Korea. Washington Times, March 11, 1999.

44) William Perry, Testimony before the Committee of International Relations, House of Representatives, 106 ${ }^{\text {th }}$ Congress, $1^{\text {st }}$ Session, October 13, 1999. 
with ROK North Korea policy. The Sunshine Policy comprised a principle that the South Korean government would not try to absorb the North and not provoke its collapse in favour of a policy stressing cooperation and confidence building today to induce the North to open up gradually. ${ }^{45}$ ) The Kim Dae-jung government adopted the liberal approach towards North Korea to achieve the realist end, namely Korean unification. The Perry team understood this policy orientation of the Kim Dae-jung government and tried to deal with North Korea as it was. ${ }^{46)}$

\section{$\mathrm{V}$. Influence of the ROK}

U.S. foreign policy is made and executed within a mass of checks and balances involving Congress, law, and often by competing branches of the Executive. In addition to those internal actors, external actors cannot be ignored in making U.S. foreign policies. As will be seen in the following, the ROK government under President Kim Dae-jung, along with Japan and China, influenced U.S. policy over North Korean nuclear and missile issues. On the critical point of U.S. North Korea policy, internal and external actors were struggling to exercise more influence over the U.S. government. The U.S. Congress and conservatives in the government attempted to alter U.S. policy towards North Korea into a more hard-line one, whereas the Kim Dae-jung government tried to nail down a policy of engagement towards North Korea. To achieve this goal, the Kim government took advantage of liberal policy tools.

\section{Shared Values: Political Liberalism, Democracy and Engagement of North Korea}

\section{(1) Political Liberalism and Democracy}

Political liberalism prevails in South Korea in the post-Cold War era. Jang points to the two factors that caused this orientation. First, the growth of civil society and the economy made liberalism more compelling. This development made Koreans more

45) Three principles of the Sunshine Policy were made public in President Kim Dae-jung's inaugural address: (1) the South will not tolerate any military provocation from the North; (2) the South will not harm the North or try to achieve reunification by forcibly absorbing the North; (3) the two sides should peacefully co-exist through reconciliation and cooperation. Kim Dae-jung, Inaugural Address, Seoul, February 25, 1998.

46) Interview with Wendy Sherman, Advisor to Secretary of State 1997-2001, the Albright Group in Washington D.C., October 12, 2004. 
interested in the enlargement of personal liberty. Second, the dramatic change in the international order and the liberal competitiveness following the demise of the Cold War affected the Koreans' mind-set. ${ }^{47)}$ In institutional aspects, South Korea has developed a mature democratic system especially since the activation of civil society movements in 1987. After the June Uprising in 1987, civil movement organizations such as the Citizens' Coalition for Economic Justice(CCEJ), the Korean Federation for Environmental Movements(KFEM) and the People's Solidarity for Participatory Democracy(PSPD) were established and they have contributed to the democratic consolidation by mobilizing the new middle class and spreading democracy throughout civil society. ${ }^{48)}$ The transition in South Korea in the late 1980s and 1990s featured the tolerance of political opposition, the self-regulation of the mass media, and local political autonomy. ${ }^{49)}$ Such features have been consolidated by political reforms conducted by the Kim Young-sam(19931997) and the Kim Dae-jung(1998-2002) governments. This change in Korean politics does not mean that South Korea transformed itself from the realist to liberal paradigm as a state. It still pursued realist ends such as the increase of its influence on the U.S., its economic and military development and two Koreas' unification. However, the developing democratic system in South Korea functioned as the bedrock of shared values and the suitable basis for a continued close association with America. ${ }^{50)}$

Political liberalism is referred to as one of the salient characteristic of American politics. It is identified with its concerns for "universal human rights, religious toleration, the promotion of commerce and the sciences, and rejection of the theocratic and martial medieval ethos. ${ }^{51)}$ American democracy focuses on, above all, individual freedom. In this context, Hartz maintains that "the master assumption of American political thought is the reality of atomistic social freedom." ${ }^{52)}$ The United States is well organized around

47) Jang Dong Jin, “Jayujuuiwa jeonggchijeok leadership" (Liberalism and Political Leadership), Paper delivered at the Monthly Conference of the Korean Political Science Association, Seoul, 27 September 1997, p.1.

48) Kim Ho Ki, "The State and Civil Society in South Korea, 1987-1999: Civil Movements and Democratic Consolidation”, Asian Perspective 25(1), 2001, p.242.

49) Lee Su Hoon, "Transitional Politics of Korea, 1987-1992: Activation of Civil Society", Pacific Affairs 66(3), 1993, pp.356-358.

50) Patrick Morgan, "The U.S.-ROK Strategic Relationship: A Liberal Analysis", in Donald N. Clark et al., U.S.-Korean Relations (Claremont, California: The Keck Center for International and Strategic Studies, 1995), p.97.

51) Rogers M. Smith, "The 'American Creed' and American Identity: The Limits of Liberal Citizenship in the United States," The Western Political Quarterly 41(2), 1988, p.229.

52) Louis Hartz, The Liberal Tradition in America: An Interpretation of American Political Thought since the Revolution (New York: Harcourt, Brace, and World, Inc., 1955), p.62. 
democratic principles such as free elections, the autonomy of local governments and the independence of the private sector. During the Cold War, intimacy grew between South Korea and the U.S. by virtue of the common objective, namely, the containment of communist countries. Containment led gradually to the denial of communist expansion and built the bilateral community. The community placed the strategic relationship between the two states on the broad basis of "interactions, values, and definitions of national objectives." Democratization of South Korea since 1987 stepped up the cohesion of the community with the U.S. and facilitated cooperation between the two nations.

\section{(2) Engagement of North Korea}

The ROK and the U.S. share the values of political liberalism and democracy. On the basis of these shared values, the two nations are oriented to the pursuit of peace and deterrence of military conflicts on the Korean peninsula. The Sunshine Policy purposed to engage North Korea, to dismantle the Cold War structure and to maintain peace on the Korean peninsula. President Kim insisted, before the U.S. Congress in June 1998, that the U.S. should consider lifting economic sanctions imposed on North Korea since 1950. ${ }^{53)}$ His statement flowed from the long-range strategy for the dismantlement of the Cold War structure. Under the policy, tourism to North Korea(Mount Kumgang) was opened to South Koreans in November 1998 for the first time and economic and cultural interactions were activated. In effect, the Kim Dae-jung government intended to develop the Sunshine Policy by promoting the Kumgang Mountain Project. Lim Dong-won, ROK Minister of Unification in 1999, said to Stanley Roth, Assistant Secretary for East Asian and Pacific Affairs, on a visit to Seoul that the ROK government wanted to develop its policy toward the DPRK based on promoting and expanding the Kumgang Mountain Project and that it had already made a significant contribution in helping stabilize the North Korean economy. ${ }^{54)}$ North-South trade increased to $\$ 640$ million in 2002 from $\$ 200$ million in 1998. South Korean visitors to the North amounted to 540, 000 during the Kim government which was 224 times as many as the 2405 visitors during the period $1989-1997 .^{55}$

The Sunshine Policy of the Kim Dae-jung government had in common with the Clinton administration the idea that North Korea should be engaged into the

53) Kim Dae-jung, Address to a Joint Session of Congress, Washington, D.C., June 10, 1998.

54) Telegram from the U.S. Embassy in Korea to the Department of State, Seoul 0567301 of 04 140947z, October 1999., p.4.

55) Segye Ilbo, February 24, 2003, p.9. 
international community through dialogues and that that would be the way in which stability in Northeast Asia could be secured. Gary Samore - who participated in negotiations with the North over the nuclear programme in 1993-1994, the Kumchangni and the missile issue in 1998-1999 - attested that there were fewer differences between the ROK and the U.S. in 1998-1999, adding, "[B]ecause as long as things were going good with Washington and Pyongyang then the Sunshine Policy would be free to move ahead. In 98-99, there was no big tension between Seoul and Washington, and that made it easier to manage the relationship." ${ }^{56)}$

At the end of the Clinton's term, the administration was willing to normalize the relationship with the North in return for eliminating the missile development programme. ${ }^{57)}$ Washington notified Seoul about the plan. Though North Korea's rejection aborted the plan, the idea itself was more progressive than the South expected. ${ }^{58)}$ The plan indicates that the Clinton administration pushed forward the liberal approach towards North Korea until the end of the administration as the Kim Dae-jung governmen did. These common views provided room for the ROK to voice its preferences and affect U.S. policy.

\section{Consultation Norms: Government-level Consultations, Policy Consistency, Leadership Beliefs and International Organization}

\section{(1) Government-level Consultations}

The Kim government became active in voicing its opinions when the Clinton administration began to review its North Korea policy. This attitude made the Americans sensitive about South Korea's stance. U.S. Coordinator on North Korea Policy William Perry was enthusiastic to reach a consensus on North Korea policy between South Korea, Japan and China. In particular, he stressed the importance of the ROK government's opinion: "I requested these meetings(with President Kim Dae-jung, National Security Advisor Lim Dong-won and other officials) because I believe that the views of the Korean government are an essential input into the policy review. ${ }^{59)}$ Wendy

56) Interview with Gary Samore, Senior Director for Non-proliferation and Export Controls at the National Security Council in 1996-2000, Institute of International and Strategic Studies (IISS), London, February 24, 2004.

57) Interview with Selig Harrison, Research Fellow in CIP (Center for International Policy), CIP in Washington D.C., October 6, 2004.

58) Interview with Lee Yong-joon, Director of North America Division I of the Ministry of Foreign Affairs and Trade, Korean Peninsula Energy Development Organization (KEDO), New York, March 29, 2004.

59) William Perry, Arrival Statement, Kimpo Airport, Seoul, March 8, 1999. 
Sherman, Advisor to Secretary of State Madelaine Albright, also said to a delegation from the Korean National Assembly that the main consideration of the Perry team was the reaction of Congress and the stance of the South Korean government. ${ }^{60)}$ U.S. policymakers' mind-set was based on the idea that U.S. policy towards North Korea can be feasible when it takes account of South Korea's opinions. It was established by talks with South Korean top decision-makers.

At the November 1998 summit, President Kim reminded President Clinton of the effectiveness of the engagement policy by quoting in detail the activation of economic trade between North and South Korea, the progress in the Four Party Talks and NorthSouth Ministerial Dialogues. He also elaborated on the disadvantages to the ROK and the U.S. if the reconciliation policy was discarded. ${ }^{61)}$ At the same time, he emphasized the importance of ROK-U.S. cooperation to reduce tensions on the Korean peninsula. ${ }^{62)}$ The July 1999 summit between President Kim and Clinton was also a forum for coordination on the approach towards North Korea. Kim reaffirmed that he would push for the engagement policy in spite of North Korea's recent provocative actions and Clinton declared again that he would support the policy. ${ }^{63)}$ Perry stated, at a Congress hearing three months later, that a successful U.S. policy would require steadfastness and persistence even in the face of provocations. ${ }^{64)}$ This statement of Perry's suggests Kim's remarks at the July 1999 summit.

Furthermore, President Kim initiated a specific process, namely a "package deal" and proposed to solve North Korean problems through the process between Washington and Pyongyang when he received Perry in December $1998 .{ }^{65)}$ He reiterated the idea whenever he had opportunities to talk about the North Korean issue. Kim's efforts along with a variety of talks on varied levels affected the Perry report. Perry himself admitted the effect of Kim's idea by saying, "the Perry process was possible since there was President Kim's engagement policy." ${ }^{66)}$

60) Joongang Ilbo, February 24, 1999, p.12.

61) Hankook Ilbo, November 22, 1998., p.2.

62) ROK Reveals 4-stage Plan to Avert Nuclear Crisis, Foreign Broadcast Information Service (FBIS), December 8, 1998., p.5.

63) William Clinton, Remarks at a Joint Press Conference with President Kim Dae-jung, the While House, July 3, 1999.

64) William Perry, Statement before the Committee of International Relations, House of Representatives, 106 ${ }^{\text {th }}$ Congress, $1^{\text {st }}$ Session, October 13, 1999.

65) ROK Reveals 4-stage Plan to Avert Nuclear Crisis, Foreign Broadcast Information Service (FBIS), December 8, 1998., p.5. 
Perry also had frequent consultations with Lim Dong-won, President Kim' National Security Advisor. They met eight times in no more than ten months after Perry had been appointed the Policy Coordinator on North Korea in November 1998. ${ }^{67)}$ Wendy Sherman in Perry's team had fourteen official dialogues with South Korean diplomats during the policy review. ${ }^{68)}$ Whenever Lim met Perry, Lim explained that the Sunshine Policy was the only policy that the U.S. and South Korea should apply to North Korea. When he visited the U.S. in January 1999 he presented the details of the comprehensive approach towards North Korea. Two months later, Perry revisited South Korea and consulted with the ROK government over his first draft. According to Korean high officials who saw the draft of the Perry report, its contents were not far from the Korean proposal suggested by Lim two months previously. ${ }^{69)}$

Below the ministerial level, Charles Kartman, U.S. Special Envoy for Korean affairs maintained close cooperation with Kwon Jong-rak, Director of the North American Affairs Bureau of the Korean Ministry of the Foreign Affairs and Trade. Kartman came to South Korea in November 1998 to inform Kwon of the North Korean attitude after he had visited North Korea. The U.S. special envoy delivered the North's demands, such as monetary compensation for access to the Kumchangni site, to his South Korean counterpart and collaborated on the ROK-U.S. joint reaction. Kartman hoped to "keep the South Korean policy-makers informed and to be guided by their advice at each stage of serious talks with North Koreans." ${ }^{70)}$ Diplomats at each level in the Clinton and Kim Dae-jung government had a very close relationship and policy coordination was conducted on the ground of the relationship. ${ }^{71)}$

Perry promised that the Sunshine Policy of the Kim Dae-jung government would be the bedrock of U.S. North Korea policy after he had discussed North Korea policy with South Korean top policy-makers during his second visit to Seoul. He also admitted, at a talk with reporters in the National Press Club, that his stance, as a U.S. policy maker, had moderated from the tough one as an independent analyst and as an author of

66) William Perry, Press Conference, Jeju Island, South Korea, June 17, 2001, Hanyoreh Shinmun, June 18, 2001., p.22.

67) Dongah Ilbo, October 9, 2003, p.12.

68) Interview with Wendy Sherman, Advisor to Secretary of State 1997-2001, the Albright Group in Washington, October12, 2004.

69) Chosun Ilbo, March 10, 1999., p.3.

70) Korea Herald, November 20, 1998., p.3.

71) Interview with Gary Samore, Senior Director for Nonproliferation and Export Controls at the National Security Council 1996-2000, February 24, 2004. 
Preventive Defense. ${ }^{72)}$ After he completed his report, he said, in October 1999, that his recommendation of a comprehensive strategy had been developed in close consultation with the governments of the Republic of Korea and Japan. ${ }^{73)}$ More frankly and clearly, he stated that senior officials in the ROK and Japan government helped shape the findings and conclusions of the report, and that he reviewed it with them "in great detail." Wit) With such a result, the Seoul government was very satisfied. President Kim Dae-jung as well as high officials expressed their pleasure. ${ }^{75}$ Some South Korean officials gave high marks not only to its contents but also to the fact that it had been formulated through close consultation with South Korea. ${ }^{76)}$

\section{(2) Policy Consistency of the Kim Dae-jung Government}

The Kim government achieved consultation norms vis-à-vis the U.S. administration by virtue of the two factors: the consistency of policy and leadership beliefs. The Kim Dae-jung government had been steady on foreign policy towards North Korea. This consistency enhanced the credibility of the policy in Washington and the U.S. government came to set a high value on the Sunshine Policy. Arnold Kanter, former Undersecretary of State during the senior Bush administration, estimated the Sunshine Policy: "The Sunshine Policy was deemed to be 'naïve,' but now to be a 'sensible policy' by keeping its consistency." ${ }^{77)}$ This atmosphere in the U.S. government contributed to ROK-U.S. consultation and cooperation over the North Korean issues as the West German consistent policy towards East Germany drew the American support for German unification. West Germany pursued persistently the gradual reduction of tension between West and East Germany and tried to secure the support for the policy from the great powers. The consistency and credibility of West German policy towards East Germany brought

72) Kyunghyang Shinmun, March 13, 1999., p.4.; Washington Post, March 13, 1999., p.A01.

73) William Perry, Testimony before the Committee of International Relations, House of Representatives, 106 th $^{\text {t }}$ Congress, $1^{\text {st }}$ Session, October 13, 1999.

74) Ibid.

75) President Kim expressed his satisfaction to National Security Advisor Hwang Won-tak. Hwang reported to Stanley Roth, U.S. Assistant Secretary of State for East Asian and Pacific Affairs when he visited the Blue House on October 13, 1999. Telegram from the U.S Embassy in Korea to the Department of State, Seoul 0570902 of 03 180624z, October 1999, pp.2-3.

76) Yang Young-sik, Vice-minister of the Ministry of National Unification, applauded the Perry report, not only for its substance, but because Perry had consulted with President Kim and the ROK 4-5 times during the report's preparation when he met Richard Christenson, Deputy Chief of Mission of the U.S. Embassy in Korea on October 20, 1999. Telegram From the U.S. Embassy in Korea to the Department of State, Seoul 0597701 of 04 290550z, October 1999, p.4.

77) Arnold Kanter, Interview with the Washington correspondent of Joongang Ilbo. Joongang Ilbo, February 23, 1999., p.13. 
American support for the unification of Germany. ${ }^{78)}$ In particular, this coherent aspect of the Kim Dae-jung government's North Korea policy was in contrast to the inconsistency of the Kim Young-sam government's and it elicited the Americans' trust.

\section{(3) Leadership Beliefs}

The Sunshine Policy was implemented unflinchingly in spite of sporadic North Korean infiltrations. The policy stemmed largely from President Kim Dae-jung's beliefs. President Kim had contemplated the ways of opening North Korea and subsequent Korean unification. The Kim government could implement the engagement policy without fluctuation thanks to his clear conclusion that dialogue and economic interdependence is the best way to peace and unification on Korean peninsula. President Kim Dae-jung's beliefs and political leadership were the most influential factors which made the foreign policy towards the DPRK consistent. President Kim entirely dominated the process of making and implementing decisions concerning the DPRK, and thus the high officials in the government were determined to realize the President's beliefs. ${ }^{79)}$ The Sunshine Policy is a prominent example which shows the influence of leadership beliefs for the government policy. ${ }^{80}$

The consistency stemmed from the fact that the Kim Dae-jung government was very clear about what it wanted from North Korea. The government wanted to change the nature of the regime. The policy consistency based on Kim Dae-jung's view of North Korea made the Clinton administration trust the Kim government's policy. ${ }^{811}$ The consistent foreign policy based on the beliefs and the credibility of the Sunshine Policy in Washington helped establish consultation norms between the ROK and U.S., and they made room for South Korean influence on U.S. policy as long as it concerned North Korea. The Perry report, in reality, referred to the role of President Kim's beliefs: "As a leader of great international authority, as our ally, and as the host to 37,000 American troops, the views and insights of President Kim are central to accomplishing U.S. security objectives on the Korean Peninsula." ${ }^{22)}$

78) Park Young Ho, Hangukui tongiloegyo jeollyak (The Strategy of Korean Diplomacy in terms of Reunification) (Seoul: Tongil yeonguwon, 1999), p.48.

79) Kim Ho Ki, "The State and Civil Society in South Korea, 1987-1999: Civil Movements and Democratic Consolidation", Asian Perspective 25(1), 2001.

80) Ibid.

81) Gil Jung Woo, "Mijeongbuui daebukjeongchaek banghyanggwa hangukui daemi mit daebukjeollyak" (U.S. policy towards North Korea and South Korean strategy towards the U.S and North Korea), Gukgajeollyak 5(1), 1999. 


\section{(4) International Organizations}

In reality, the Kim government took advantage of international organizations to consult with the Clinton administration. The Trilateral Coordination and Oversight Group(TCOG) between the ROK, the U.S. and Japan, the SCM(Security Consultative Meeting) between the ROK acted effectively ROK-U.S. policy coordination. ${ }^{83)}$ In particular, the TCOG functioned as a main forum for South Korean influence through consultations. Five TCOG meetings were held before the Perry report came out in September 1999 since it had been established in April 1999 - once a month - for ROKU.S.-Japan policy coordination. Assistant Secretary-level representatives discussed and coordinated concrete policy orientations towards North Korea. It was, as it were, a field command which decided specific directions within the framework defined by summit meetings and ministerial dialogues. $\left.{ }^{84}\right)$ When the ROK and the U.S. confronted a crucial point in terms of North Korea policy due to the North's infiltration of the Northern Limit Line(June 15) and North Korea's detention of a South Korean tourist to Mount Kumgang(June 19), South Korea persuaded the U.S. to retain its engagement with North Korea in the TCOG meeting in Washington on June 25-26, 1999. South Korean representatives explained to the Americans that such provocations were a sort of North Korean tactic to increase its bargaining leverage in the on-going Under-Secretary-level talks over the North Korean missile programme between Charles Kartman, U.S. Special Envoy for Korean Peace Talks and Kim Gye-kwan, DPRK Vice Foreign Minister. The U.S. accepted South Korea's assertion, Japan also agreed to continuous engagement and consequently, the engagement policy was maintained as a core element on the draft of the Perry report. ${ }^{85)}$ Swift and effective consultation within the systematic procedure of the TCOG - which was established through frequent meetings - played a key role in efficient coordination.

The American government was willing to respect South Korean opinions in the institutional cooperation within the TCOG. Dealing with the Kumchangni problem, the

82) Review of United States Policy Toward North Korea: Findings and Recommendations, Unclassified Report by Dr. William J. Perry, U.S. North Korea Policy Coordinator and Special Advisor to the President and the Secretary of State, Washington, D.C., October 12, 1999, p.2.

83) In terms of the minimum number of units that must belong to an international organization, bilateral, trilateral, plurilateral, regional or universal relationships could be included in the concept of international organization. Therefore, the TCOG and SCM can be categorized as international organizations. See Michael Haas, "A Functional Approach to International Organization," The Journal of Politics 27(3), 1965, p.500.

84) Chosun Ilbo, September 9, 1999., p.3.

85) Segye Ilbo, June 28, 1999., p.3. 
Americans attempted to change the main contents of the 1994 Agreed Framework. They proposed, at TCOG meetings, a change to go from two nuclear reactors - which were promised by the 1994 Agreed Framework - down to one reactor in order to put on the table non-nuclear energy that could be delivered much earlier in the process and get from the North Korean side a freeze on the nuclear programme much earlier in the process. But the Koreans said they did not want that approach and the U.S. respected its ally's veto. ${ }^{86)}$ During the DPRK-U.S missile negotiations, the TCOG was also the primary instrument of policy coordination. Washington, Seoul and Tokyo cooperated to send transparent messages to Pyongyang about the punitive consequences of another missile launch. This collaboration confounded DPRK intentions of driving a wedge between the allies. ${ }^{87}$

The ROK and the U.S. have been discussing military policy in the Security Consultation Meeting(SCM) since 1968. The main focus has been strengthening ROKU.S. deterrence against North Korea. However, the SCM in January 1999 expanded its agenda to ROK-U.S. foreign policy vis-à-vis the DPRK. The meeting, of course, dealt with the counteraction to the possible North Korean attack on South Korean territory and concluded that the U.S. would support South Korea by all means including nuclear umbrella. Besides this, ROK Defence Minister Chun Yong-taek and U.S. Defense Secretary William Cohen emphasized that dialogue between the authorities of the South and the North should be resumed to implement the Agreement on Reconciliation, Nonaggression, and Exchange and Cooperation between the South and the North(the South-North Basic Agreement) of 1992. Secretary Cohen especially expressed his support for the three principles of the ROK government's North Korea policy: no tolerance for any armed attack, no pursuit of unification by absorption, and promotion of reconciliation through exchange and cooperation. Secretary Cohen also appreciated that the ROK government was implementing a forward-looking engagement policy towards North Korea, based on the separation of political and economic issues. ${ }^{88)}$ With regard to the Kumchangni and missile issue, Cohen indicated, at a press conference after the meeting, that there was no conclusive evidence of a violation of the Agreed

86) Interview with Charles Kartman, U.S. representative to the TCOG and the Four Party Talks, Korean Peninsula Energy Development Organization, New York, March 29, 2004.

87) Victor Cha, "Berlin: What have we learned and where do we go from here?" Nautilus Policy Forum Online, September 17, 1999. http//www.nautilus.org/fora/ security/9907A_Cha.html (accessed on May 3, 2004).

88) Joint Communique of the 30th ROK-U.S Security Consultation Meeting, Article 3, Seoul, January $15,1999$. 
Framework. ${ }^{89)}$ This stand differed from his November 1998 statement: "It would seem to me not to be a prudent course to wait until the facility(the Kumchangni site) is completed." The SCM in January 1999 actively contributed to advancing ROK-U.S. common understanding and to compromise on foreign policy concerning North Korea. A variety of institutions from working-level to high-level were intertwined in building consultation norms and elaborating a consensus on North Korea policy.

\section{Transnational, Transgovernmental and Cress-level Coalitions}

During the Kim Dae-jung government, non-state actors such as scholars and academic institutes interacted with their American counterparts. Academic conferences functioned as forums for the exchange of views on North Korea and on ways to influence U.S North Korean policy. In a seminar in Seoul in March 1999, experts from South Korea and the U.S. discussed North Korea policy and William Perry was invited there. He refrained himself from speaking in the seminar and listened to the arguments by experts very carefully. $\left.{ }^{90}\right)$ An international conference held in Washington,D.C. in May 1999 also acted as a forum for active discussion over U.S. North Korean policy. A number of figures participated in the conference titled "The Sunshine Policy of the Kim Dae-jung Government": Robert Gallucci, former Assistant Secretary of State for Political-Military Affairs; Donald Gregg, former Ambassador to Seoul; Dusaix Anderson, then Executive Director of Korean Peninsula Energy Development Organization; Hong Soon-young, then Foreign Minister of South Korea. The participants discussed very actively U.S North Korean policy and ROK-U.S. relations. Some of them argued that the Perry report should reflect the engagement policy of the Kim Dae-jung government, others were afraid that the engagement policy would not be effective if North Korea did not comply with it or if the U.S. were not enthusiastic in implementing concrete actions to accommodate the North. Nevertheless, the atmosphere of the conference, according to Professor Moon Chung-in, one of the participants, was inclined to favour the engagement policy. ${ }^{91)}$ Besides these conferences, a number of seminars were hosted by the Korean Political Science Association, the Korean Research Foundation, the National Council of Churches in Korea and the press in 1998 and 1999 and they served as arenas in which Korean and American experts communicated their ideas in terms of North

89) William Cohen, U.S. Defence Secretary and Chun Yong-taek, ROK Defence Minister, Press Conference, Seoul, January 15, 1999.

90) Chosun Ilbo, March 27, 1999., p.5.

91) Munhwa Ilbo, May 24, 1999., p.6. 
Korea and North Korean policy. Analysts such as Selig Harrison in the Center for International Policy and Don Oberdorfer at Johns Hopkins University believe that arguments suggested in conferences and seminars over the Korean peninsula in Washington and Seoul affected the Perry team and President Clinton. ${ }^{92)}$

Transgovernmental connections could also be effectively utilized by small states to reinforce the influence of "like-minded factions in large states when officials in them are internally divided." ${ }^{93)}$ In practice, ROK-U.S. policy coordination was facilitated by informal relations between the two nations' diplomats. ${ }^{94)}$ Transgovernmental, informal relations between ROK-U.S. officials have enabled each nation to understand deeply the background of the partner's stance and has made each other's posture more flexible. ${ }^{95)}$ The element of personal trust played a role in ROK-U.S. cooperation concerning the North Korean nuclear and missile issue in that South Korean and American diplomats' inclination functioned as a basis of cooperation and negotiation between the two nations. ${ }^{96)}$ South Korean diplomats under Kim Dae-jung established coalitions with the dovish faction in the U.S. government - mainly in U.S. Department of State - and delivered their ideas to the U.S. effectively.

During the Kim Dae-jung government, the informal relationship between President Kim Dae-jung and President Clinton played a great role in facilitating the South Korean impact on U.S. foreign policy. When Cho Myong-rok visited Washington in October 2000 and put on the table the possibility of the missile deal, he insisted on a North Korea-U.S. summit meeting which the Americans were really reluctant to do. They quickly communicated the North Korean proposal to both Seoul and Tokyo and they received a very strong answer back from President Kim Dae-jung. He replied, "Yes. Go try for that." President Clinton accepted Kim's assertion. Though the summit was not

92) Interview with Selig Harrison, Research Fellow in CIP(Center for International Policy), CIP in Washington, October 6, 2004.; Interview with Don Oberdorfer, Distinguished Journalist in Residence and Adjunct Professor of International Relations at Johns Hopkins University, October 6, 2004.

93) Jeffrey W. Knopf, "Beyond two-level games: domestic-international interaction in the intermediaterange nuclear forces negotiations," International Organization 47(4), 1993, p.606.

94) Interview with Jang Jae-ryong, Assistant Minister of Foreign Affairs and Trade 1999-2000, Institute of Foreign Affairs and National Security in Seoul, September 20, 2004.

95) Interview with Lee Yong-joon, Director of North American Division I of the Ministry of Foreign Affairs and Trade in 1998, March 29, 2004.

96) Interview with Charles Kartman, U.S. Special Envoy for the Korean Peace Talks 1998-2000, March 29, 2004. 
held due to North Korea's objection to demands for the entire elimination of the missile programme, Clinton was ready to go to the summit meeting with North Korean leader Kim Jong-il. There was a lot of trust and personal respect between President Clinton and President Kim Dae-jung. ${ }^{97)}$ Such respect made possible President Kim's influence on President Clinton's decision-making.

In July 1999, the Council on Foreign Relations(CFR) issued a report titled U.S. Policy toward North Korea: a Second Look. The report recommended that the U.S. should not end attempts at diplomacy even if North Korea conducted another missile test. ${ }^{98)}$ In particular, the report noted that the North Korean missile test had not violated any existing agreements between the United States and North Korea and should not affect the implementation of the Agreed Framework. ${ }^{99)}$ This perspective was in line with Seoul's. This view was formulated through South Korean coalitions with the CFR. When the CFR sent Korea report researchers to Seoul, the South Korean diplomats were very active in discussing Korean peninsular affairs with them and tried their best to get South Korea's engagement approach reflected in the CFR report. ${ }^{100)}$ This could be an appropriate example for a "cross-level coalition" suggested by Knopf. Knopf underlines the role of cross-level processes which entail communication between leaders or government officials on one side and the public on the other. ${ }^{101)}$ Hyundai Construction - a private construction company which was involved in the Kumgang Mountain Project - also played a part in the maintenance of the engagement policy in the Perry process by sending a message to the U.S. worrying about the effect of a hard-line policy. When Kim Yoon-kyu, Hyundai Construction President had a meeting with Richard Christenson, Deputy Chief of Mission of the U.S. Embassy in Seoul on March 8, 1999, he referred to press claims that Perry's report would conflict with President Kim's Sunshine Policy and expressed concern about the potential for raising tensions between North Korea and the ROK and the U.S. ${ }^{102)}$ At the time, he tried to nail down operational details of investments

97) Interview with Charles Kartman. Kartman emphasized the close relationship between the two president by comparing it to Winston Churchill-Franklin Roosevelt relationship and said that President Kim had as much effect on President Clinton as Prime Minister Churchill had on President Roosevelt.

98) Council on Foreign Relations, U.S. Policy toward North Korea: A Second Look, July 1999, p.4.

99) Ibid., p.16.

100) Interview with Kim Young-mok, Deputy Director of North Korean Affairs Bureau of the Ministry of Foreign Affairs and Trade 1998-2000, March 26, 2004.

101) Knopf, op. cit., p.608.

102) Telegram from the U.S. Embassy in Korea to the Department of State, Seoul 0146502 of 03 110005z, March 1999., p.3. 
in tourism facilities in Kumgang Mountain ${ }^{103)}$ and the Kumgang Mountain Project was regarded as a symbol of the Sunshine Policy. So, his concern could not be dealt with as just an appeal from a private company.

\section{Domestic Pressures: Public Opinion and the Press}

The Sunshine Policy commanded broad support in South Korea. Most opinion polls showed that more than $60 \%$ of the respondents supported the policy. This high support rate had been kept even when the general support rate for the Kim Dae-jung government fell and contributed to the stability of the government. ${ }^{104)}$ For instance, an opinion poll undertaken by the Hangyoreh Shinmun showed that $70.5 \%$ of the respondents approved of the Sunshine Policy. In particular, 95.5\% of surveyed intellectuals gave an affirmative answer to the expected effect of the Sunshine Policy. ${ }^{105)}$ Paik points out that such support had been sustained during President Kim's tenure despite his sons' corruption scandals and that the Sunshine Policy had achieved a "national consensus." ${ }^{106)}$ Such high support in the public reinforced the South Korean position in implementing foreign policy and in attempts to affect U.S. policy.

The Kim government also exploited the press to command support from the public and affect U.S. policy. The South Korean government released the dialogue between President Kim and Perry, U.S. Coordinator on North Korean policy on December 7, 1998, which included the concrete proposal of South Korea, that is, a package deal exchanging lifting economic sanctions, economic aid and normalization of diplomatic relations for a halt to the nuclear programme and missile development - between the U.S. and North Korea. The Clinton government was outraged about the release without any consultation. ${ }^{107)}$ The Kim government preferred a package or comprehensive deal and disclosed the proposal of the strategy without U.S. consent. The Kim Dae-jung

103) Telegram from the U.S. Embassy in Korea to the Department of State, Seoul 0146501 of 03 110005z, March 1999., p.2.

104) Park Sun Won, "Hatbyeotjeongchaekgwa yeoron: jisokseonggwa byeonyongui gwanjeomeseobon siljeungbunseok" (The Sunshine Policy and Public Opinion: Empirical Analysis of Surveys from the Perspective of Continuity and Alteration), Hangukgwa gukjejeongchi 18(2), 2002, p.131.

105) Hangyoreh-sinmun (Hangyoreh Daily), 23 February 1999., p.4. The opinion poll conducted interviews with 700 people. Apart from this, 218 intellectuals were surveyed. In this poll, intellectuals comprised $\mathrm{PhD}$ candidates and PhDs.

106) Paik Haksoon, "Assessment of the Sunshine Policy: A Korean Perspective," Asian Perspective 26 (3), 2002, p.29.

107) Gil, op. cit., p.136. 
government attempted to mobilize South Korean domestic pressures for the comprehensive deal to press the U.S. to accept the package deal by making public the proposal through the press. Even the Washington government understood that the South Korean government had its own political concerns. However, Washington "tried to ensure that that sort of thing did not happen again and that no one was surprised by what the other would say." ${ }^{108)}$

Even after the Perry report was completed, the Seoul government made efforts to encourage the Washington government to preserve the course of engagement. When Yang Young-sik, Vice-minister of the Ministry of National Unification met Richard Christenson, Deputy Chief of Mission of the U.S. Embassy in Seoul on October 20, 1999, he said that the Perry report had provided clear evidence that the U.S. supported South Korea's engagement policy and that Hyundai's meeting with Kim Jong-il ${ }^{109)}$ indicated obviously the ROK's policy was producing results with the North. Informing U.S. diplomats of the South Korean policy shift from government-to-government dialogue to encouraging greater private economic cooperation with North Korea, he referred to surveys which showed 60-70\% of Koreans supported President Kim Dae-jung's Sunshine Policy. ${ }^{10)}$ By this, it was obvious that Seoul intended the U.S. to keep supporting South Korea's engagement policy towards North Korea even after the Perry report. In this sense, the Kim Dae-jung government used public opinion and the press to raise its voice vis-à-vis the U.S. besides government-level close consultations.

\section{Factors and Circumstances for the ROK Influence}

\section{Common Views}

The fact that Seoul and Washington were like-minded in their views and approaches to the North was the bedrock of ROK-U.S. cooperation. Ideas serve "as focal points that define cooperative solutions or act as coalitional glue to facilitate the cohesion of

108) Interview with Stephen Bosworth, U.S. Ambassador to South Korea 1998-2001, March 30, 2004.

109) Reclusive North Korean leader Kim Jong-il, Chairman of DPRK National Defence Commission, met Chung Ju-young, Honorary Chairman of Hyundai (a South Korean conglomerate) on October 1, 1999. At the meeting, they agreed to develop a large-scale industrial park on the West coast of North Korea. Kookmin Ilbo, October 2, 1999., p.1.

110) Telegram from the U.S. Embassy in Korea to the Department of State, Seoul 0597701 of 04 290550z, October 1999, p.4. 
particular groups." $\left.{ }^{111}\right)$ Furthermore, shared beliefs between nations are essential to the maintenance of cooperation. Ideas, social norms, institutions, and shared expectations may influence the way actors choose to cooperate. ${ }^{112)}$ Both the Kim Dae-jung and Clinton administrations shared the idea that North Korea should and could be a member of the international community by way of engagement and encouraged each other to improve relations with North Korea. In the process of William Perry's policy review, the likemindedness was intensified and in return, ROK-U.S. consultations became closer on the basis of the intensified like-mindedness.

\section{Leadership Beliefs, Policy Consistency and International Organizations}

Leadership beliefs are conceived to be more influential in developing countries than in advanced nations. Hart explains the significant role of elite belief systems in developing countries by citing the cases of Latin American nations. ${ }^{113)}$ Hart's account applies to South Korean cases. In Korean politics, presidential orientations or views on policies have played important parts in determining state actions. The lack of institutionalized checks and balances on the president has provided his mandate with strong influence. Even the bureaucracy - though it is normally influential in policy-making and policyimplementing - has been weak compared to presidential influence. ${ }^{114)}$ President Kim Dae-jung's beliefs also served as a determinant in formulating and maintaining the government's foreign policy. They also made possible that the government was coherent in implementing its foreign policy. The coherence yielded confidence in policy. In addition, international organizations such as the TCOG, the SCM contributed to the

111) Judith Goldstein and Robert O. Keohane, "Ideas and Foreign Policy: An Analytical Framework," in Judith Goldstein and Robert O. Keohane eds., Ideas and Foreign Policy: Beliefs, Institutions, and Political Change,(London: Cornell University Press, 1993), p.12. Ideas, on Goldstein's and Keohane's accounts, are defined as "beliefs held by individuals" and they comprise three types of beliefs: world views, principled beliefs and causal beliefs. World views mean "the universe of possibilities for action" and include views about cosmology and ontology as well as about ethics. Principled beliefs consist of "normative ideas that specify criteria for distinguishing right from wrong and just from unjust." Causal beliefs are "beliefs about cause-effect relatiohships which derive authority from the shared consensus of recognized elites." See ibid., pp.3, 8-10.

112) Geoffrey Garrett and Barry R. Weingast, "Ideas, Interests, and Institutions: Constructing the European Community's Internal Market," in Judith Goldstein and Robert O. Keohane eds., Ideas and Foreign Policy: Beliefs, Institutions, and Political Change (London: Cornell University Press, 1993), p.176.

113) Jeffrey A. Hart, "Cognitive Maps of Three Latin American Policy Makers", World Politics 30(1), 1977, p.115.

114) Hahm Sung Deuk and Christopher L. Plein, "Institutions and Technological Development in Korea: The Role of the Presidency," Comparative Politics 38(1), 1995, p.58. 
institutionalization of ROK-U.S. consultation. The linkage of these factors with consultation is portrayed as this figure:

〈Figure 4〉 Leadership Beliefs, Policy Consistency, International Organization and Consultation

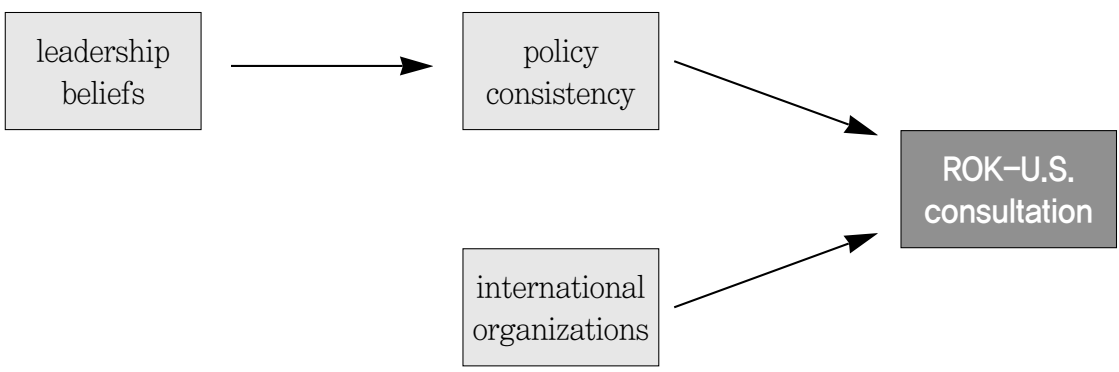

\section{Transboundary Coalitions}

The informal relationship between ROK and U.S. government officials during the Kim Dae-jung government was so close as to facilitate ROK-U.S. cooperation and South Korean influence. The South Korean government also recognized the importance of non-governmental institutions which researched U.S. foreign policy. It fully cooperated with them and got its policy orientations reflected in their policy reports. Expert community also helped South Korea voices to be heard in U.S. policy-making. Korean and American experts specialized in Korean peninsula affairs discussed U.S. North Korea policy and made public their arguments. Ideas inspired by them were embraced by policy-makers in the U.S. government. An "epistemic community" in Haas's phrase facilitates policy coordination. ${ }^{115)}$ National epistemic communities emerge and function in a single country, but they can also become transnational when they disseminate their ideas through conferences, journals, research collaboration, and a variety of informal communications and contacts. The experts can cause international policy coordination when they cooperate through transnational and transgovernmental channels. ${ }^{116)}$ Academic

115) Haas defines 'epistemic community' as "a network of professionals with recognized expertise and competence in a particular domain and an authoritative claim to policy-relevant knowledge within that domain or issue-area," and may convey new patterns of reasoning to decision makers and encourage them to pursue new paths of policymaking, which may in turn lead to unpredicted or unpredictable outcomes." See, Peter Haas. "Introduction: epistemic communities and international policy coordination," International Organization 46(1), 1992, pp.2, 21.

116) Haas, op. cit., 1992, pp.17, 32. 
institutions and scholars in both countries interacted closely and policy recommendations from their communications were likely to provide references for U.S. foreign policymaking.

\section{Domestic Pressures}

South Korean public opinion bolstering the engagement of North Korea helped increase South Korean impact on the Clinton administration's approach towards North Korea. Internal constraints - domestic factions differing about what they want - can help a nation to extract concessions from the negotiation partner. U.S. governments have long used possible congressional rejection as a threat when they need to leverage concessions from opponents. ${ }^{117)}$ Putnam emphasizes the importance of internal as well as inter-state negotiations and terms the former "Level II," the latter "Level I ." ${ }_{118)}$ He also indicates that public opinion, social classes and interest groups play important roles at Level II. If actors such as public opinion or labour unions in a country resist the international agreement of the government, the agreement may be said to have failed. Thereafter, negotiators are likely to be affected by public opinion or labour unions. ${ }^{119)}$ In other words, the actors can function as a bargaining leverage and negotiators can use them to reinforce bargaining power. Public opinion on the Sunshine Policy contributed to the strengthening of South Korean influence on U.S. North Korea policy. The press is used to build up support or resonance for a certain foreign policy behavior. Policymakers or congressmen may go to the press to obtain interest and support for foreign policy proposals. ${ }^{120}$ The Kim Dae-jung government also used the press in an attempt to raise its bargaining leverage.

\section{Conclusion}

The military power of the ROK is not enough to counter threats from the DPRK. U.S.

117) Frederick W. Mayer, "Managing domestic differences in international negotiations: the strategic use of internal side-payments", International Organization 46(4), 1992, p.796.

118) Level I refers to the bargaining between the negotiators who represent each nation. It normally produces a provisional agreement which can be a final one after the domestic ratification at Level II. See Robert D. Putnam, "Diplomacy and domestic politics: the Logic of Two-level games", International Organization 42(3), 1988, p. 436.

119) Ibid., p.436.

120) Bernard C. Cohen, The Press and Foreign Policy (Princeton: Princeton University Press, 1963), p.188. 
military forces help to fill the gap. The asymmetrical alliance between the two states has limited the autonomy of the ROK governments; South Korean governments have generally been affected by - rather than affecting or consulting with - the U.S administrations in military and foreign policy. ${ }^{121)}$ The Kim Dae-jung government, however, made efforts to mediate between the DPRK and U.S., and requested that the U.S. consult with it about policy towards the DPRK. Confronting threats from North Korea, the ROK and the U.S. reacted to them from different perspectives. The South Korean government focused on the disruption of the Cold War structure and the settlement of peace on the Korean peninsula. Seoul, therefore, sought for a comprehensive solution. The Kim government believed that this approach was the best policy to accomplish Koreans' realist goals: peace and subsequent national unification.

Though it is argued that consultations between the two nations were smooth, it is not the case that there was no friction in regard to the North Korean problem. The Seoul government sometimes complained about American monopoly of information. Nevertheless, the two allies kept frequent contacts to cooperate for the main stream of North Korea policy. The policy review conducted by William Perry resulted in adopting the engagement policy in spite of the hawkish atmosphere in the U.S. caused by the Kumchangni site and missile test. This result was made by virtue of varied factors and circumstances such as common views, leadership beliefs, policy consistency, international organizations, transboundary coalitions and domestic pressures. The Kim Dae-jung government made good use of liberal policy tools to achieve a realist end, namely, influence on U.S. policy towards North Korea. Of course, the nature of the issues was different from that of the Kim Young-sam government. To make the U.S. reflect the South's opinions on its policy seemed to be easier than realizing South Korean requests towards North Korea by way of the U.S. In addition, North Korea was stubborn when it dealt with IAEA special inspections, North-South dialogues and the style of light-water reactor during the 1993-1994 negotiations. Even though the differences of the nature of the issues were considered, it could be argued that the process of ROK-U.S. consultation during the Kim Dae-jung government was more systematic and effective.

121) Jang No Soon, "Gyohwandongmaeng modelui gyohwanseong: bidaeching hanmi anbodongmaeng" (Trade-off of Trade-off Alliance Model: Asymmetrical ROK-U.S. Security Alliance), Gukjejeongchi nonchong 36(1), 1996, p.84. 


\section{〈List of Interviewees〉}

- Bosworth, Stephen. U.S. Ambassador to South Korea 1997-2001, Fletcher School, Tufts University, Massachussets, March 30, 2004.

- Campbell, Kurt. Deputy Assistant Secretary of Defence 1995-2000, CSIS (Center for Strategic and International Studies), October 6, 2004.

- Harrison, Selig. Research Fellow in CIP (Center for International Policy), CIP in Washington D.C., October 6, 2004

- Jang, Jae-ryong. Assistant Minister of Foreign Affairs and Trade 1999-2000, Institute of Foreign Affairs and National Security in Seoul, September 20, 2004

- Kartman, Charles. U.S. representative to the TCOG and the Four Party Talks, Korean Peninsula Energy Development Organization, New York, March 29, 2004.

- Kim, Young-mok. Deputy Director of North Korean Affairs of the Ministry of Foreign Affairs and Trade 1998-2000, Intercontinental Hotel in New York, March 26, 2004.

- Kirk, Mark. Counsel to the International Relations Committee in the House 19981999, Longworth House Office Building, Washington, March 23, 2004.

- Lee, Yong-joon. Director of North America Division I of the Ministry of Foreign Affairs and Trade in 1998, Korean Peninsula Energy Development Organization, New York, March 29, 2004.

- Samore, Gary. Senior Director for Non-proliferation and Export Controls at the National Security Council in 1996-2000, Institute of International and Strategic Studies (IISS), London, February 24, 2004.

- Sherman, Wendy. Advisor to Secretary of State 1997-2001, the Albright Group in Washington D.C., October 12, 2004.

- Wit, Joel. Coordinator for the 1994 U.S.-North Korea Agreed Framework 1998-1999, Center for Strategic and International Studies, March 23, 2004. 


\section{REFERENCES}

A Comprehensive Approach to North Korea, Washington, Institute for National Strategic Studies, National Defense University, March 1999.

Congressional Record, Vol.144. (Washington, D.C.: U.S. Government Printing Office, 1998).

Expressing the sense of the Congress that the commitment made by the United States, in conjunction with South Korea and Japan, to arrange financing and construction of 2 nuclear reactors for North Korea, and to provide fuel oil and other assistance to North Korea, should be suspended until North Korea no longer poses a nuclear threat to the peace and security of Northeast Asia or the United States., H.CON.RES.341., 105th Congress, 2nd Session, October 8, 1998.

Joint Communique of the 30th ROK-U.S Security Consultation Meeting, Seoul, January 15, 1999.

Mistrust and the Korean Peninsula: Dangers of Miscalculation, United States Institute of Peace, Special Report 38, October 1998.

Review of United States Policy Toward North Korea: Findings and Recommendations, Unclassified Report by Dr. William J. Perry, U.S. North Korea Policy Coordinator and Special Advisor to the President and the Secretary of State, Washington, D.C., October 12, 1999.

ROK Reveals 4-stage Plan to Avert Nuclear Crisis, Foreign Broadcast Information Service (FBIS), December 8, 1998.

Telegram from the U.S. Embassy in Korea to the Department of State, Seoul 0567301 of 04 140947z, October 1999.

Telegram from the U.S. Embassy in Korea to the Department of State, Seoul 0146501 of 03 110005z, March 1999.

Telegram from the U.S. Embassy in Korea to the Department of State, Seoul 0146502 of 03 110005z, March 1999.

Telegram from the U.S Embassy in Korea to the Department of State, Seoul 0570902 of $03180624 z$, October 1999.

Telegram from the U.S. Embassy in Korea to the Department of State, Seoul 0597701 of 04 290550z, October 1999.

U.S. Policy toward North Korea: A Second Look, Council on Foreign Relations, July 1999. 
Clinton, William. Remarks at a Joint Press Conference with President Kim Dae-jung, the While House, July 3, 1999.

Cohen, William. Defence Secretary, News Conference, November 23, 1998.

Cohen, William, U.S. Defence Secretary and Chun Yong-taek, ROK Defence Minister, Press Conference, Seoul, January 15, 1999.

Kim, Dae-jung. Address to a Joint Session of Congress, Washington, D.C., June 10, 1998.

Perry, William. Testimony before the Committee of International Relations, House of Representatives, 106 ${ }^{\text {th }}$ Congress, $1^{\text {st }}$ Session, October 13, 1999.

Guardian, November 26, 1998.

Korea Herald, November 20, 1998; October 26, 1999.

Korea Times, September 20, 1998.

Los Angeles Times, February 13, 1999.

New York Times, August 17, 1998.

Time, August 10, 1998.

Washington Post, August 22, 1998.

Washington Times, March 11, 1999.

Amin, Samir (1974) Accumulation of a World Scale: A Critique of the Theory of Underdevelopment, 2 volume, New York: Monthly Review Press.

Cohen, Bernard C. (1963) The Press and Foreign Policy, Princeton: Princeton University Press.

Carter, Ashton and William Perry (1999) Preventive Defense, Washington, D.C.: Brookings Institution Press.

Cha, Victor (1999) "Berlin: What have we learned and where do we go from here?" Nautilus Policy Forum Online, September 17, 1999.

Deutsch, Karl W. 1969. Political community and the North Atlantic area: International Organization, Westport, Connecticut: Greenwood Press.

Frank, Andre Gunder (1969) Latin America: Underdevelopment of Revolution: Essays on the Development of Underdevelopment and the Immediate Economy, New York: Monthly Review Press.

Garret, Geoffrey and Barry R. Weingast (1993) "Ideas, Interests, and Institutions: Constructing the European Community's Internal Market," in Judith Goldstein 
and Robert O. Keohane eds., Ideas and Foreign Policy: Beliefs, Institutions, and Political Change, London: Cornell University Press, pp.173-206.

Goldstein, Judith and Robert O. Keohane (1993) "Ideas and Foreign Policy: An Analytical Framework," in Judith Goldstein and Robert O. Keohane eds., Ideas and Foreign Policy: Beliefs, Institutions, and Political Change, London: Cornell University Press, pp.3-30.

Haas, Michael (1965) “A Functional Approach to International Organization," The Journal of Politics 27(3), pp.498-517.

Haas, Peter (1992) "Introduction: epistemic communities and international policy coordination," International Organization 46(1), pp.1-35.

Hahm, Sung Deuk and Christopher L. Plein (1995) "Institutions and Technological Development in Korea: The Role of the Presidency," Comparative Politics 38(1), pp. $55-76$.

Handel, Michael (1981) Weak States in the International System, London: Frank Cass.

Hart, Jeffrey A. (1977) "Cognitive Maps of Three Latin American Policy Makers”, World Politics 30(1), pp.115-140.

Hartz, Louis (1955) The Liberal Tradition in America: An Interpretation of American Political Thought since the Revolution, New York: Harcourt, Brace, and World, Inc.

Jervis, Robert (1986) "From Balance to Concert: A Study of International Security Cooperation," in Cooperation under Anarchy, edited by Kenneth Oye, Princeton, N. J: Princeton Universithy Press, pp.58-79.

Knopf, Jeffrey W. (1993) "Beyond two-level games: domestic-international interaction in the intermediate-range nuclear forces negotiations," International Organization 47(4), pp.599-628.

Keohane, Robert O. (1971) "The Big Influence of Small Allies," Foreign Policy 2, pp.161-182.

Keohane, Robert O. (1989) International Institution and State Power, Boulder, Colorado: Westview.

Kim, Ho Ki (2001) "The State and Civil Society in South Korea, 1987-1999: Civil Movements and Democratic Consolidation”, Asian Perspective 25(1), pp.229-248.

Lee, Su Hoon (1993) "Transitional Politics of Korea, 1987-1992: Activation of Civil Society", Pacific Affairs 66(3), pp.351-367.

Mayer, Frederick W. (1992) "Managing domestic differences in international negotiations: the strategic use of internal side-payments", International Organization 46(4), pp.793-818. 
Morgan, Patrick (1995) “The U.S.-ROK Strategic Relationship: A Liberal Analysis”, in Donald N. Clark et al., U.S.-Korean Relations, Claremont, California: The Keck Center for International and Strategic Studies, pp.81-105.

Morgenthau, Hans (1985) Politics Among Nations: The Struggle for Power and Peace, Sixth Edition, Revised by Kenneth W. Thompson, New York: McGraw-Hill, Inc. Paik, Haksoon (2002) "Assessment of the Sunshine Policy: A Korean Perspective," Asian Perspective 26(3), pp.13-35.

Prebisch, Raul (1962) "The Economic Development of Latin America and Its Principal Problems," Economic Bulletin for Latin America 7, pp.1.22.

Putnam Robert D. (1988) "Diplomacy and domestic politics: the Logic of Two-level games”, International Organization 42(3), pp.427-460.

Reid, George L. (1974) The Impact of Very Small Size on the International Behavior of Microstates, London: Sage Publications.

Risse-Kappen, Thomas (1995) Cooperation among Democracies: The European Influence on U.S. Foreign Polics, Princeton: Princeton University Press.

Smith, Rogers M. (1988) “The 'American Creed' and American Identity: The Limits of Liberal Citizenship in the United States," The Western Political Quarterly 41(2), pp. 225-251.

Waltz, Kenneth (1979) Theory of International Politics, Reading, Massachusetts: Addison-Wesley.

Wendt, Alexander (1992) "Anarchy is what States Make of it: The Social Construction of Power Politics," International Organization 46(2), pp.391-425.

Kim, Dae-jung, Inaugural Address, Seoul, February 25, 1998.

Chosun Ilbo, August 28, 1998.; March 10, 1999.; March 27, 1999.; September 9, 1999.

Dongah Ilbo, October 9, 2003.

Hangyoreh Shinmun, 23 February 1999.; March 10, 1999.; June 18, 2001.

Hankook Ilbo, November 21, 1998.; November 22, 1998.; August 9, 1999.

Joongang Ilbo, December 8, 1998.; January 9, 1999.; February 24, 1999.

Kookmin Ilbo, October 2, 1999.

Kyunghyang Shinmun, March 13, 1999.

Munhwa Ilbo, November 20, 1998.; May 24, 1999.

Segye Ilbo, January 1, 1999.; June 28, 1999.; February 24, 2003. 
Gil, Jung Woo (1999) "Mijeongbuui daebukjeongchaek banghyanggwa hangukui daemi mit daebukjeollyak" (U.S. policy towards North Korea and South Korean strategy towards the U.S and North Korea), Gukgajeollyak 5(1), pp.129-158.

Jang, Dong Jin (1997) "Jayujuuiwa jeonggchijeok leadership" (Liberalism and Political Leadership), Paper delivered at the Monthly Conference of the Korean Political Science Association, Seoul, 27 September 1997.

Jang No Soon (1996) "Gyohwandongmaeng modelui gyohwanseong: bidaeching hanmi anbodongmaeng" (Trade-off of Trade-off Alliance Model: Asymmetrical ROKU.S. Security Alliance), Gukjejeongchi nonchong 36(1), 79-104.

Park, Sun Won (2002) "Hatbyeotjeongchaekgwa yeoron: jisokseonggwa byeonyongui gwanjeomeseobon siljeungbunseok" (The Sunshine Policy and Public Opinion: Empirical Analysis of Surveys from the Perspective of Continuity and Alteration), Hangukgwa gukjejeongchi 18(2), pp.121-154.

Park, Young Ho (1999) Hangukui tongiloegyo jeollyak (The Strategy of Korean Diplomacy in terms of Reunification), Seoul: Tongil yeonguwon. 